\title{
Meat characteristics of Nellore steers fed whole cottonseed ${ }^{1}$
}

\section{Dorival Pereira Borges da Costa ${ }^{2}$, Roberto de Oliveira Roça ${ }^{3}$, Quézia Pereira Borges da Costa ${ }^{4}$ Dante Pazzanese Duarte Lanna ${ }^{5}$, Erico da Silva Lima ${ }^{4}$, Wander Miguel de Barros ${ }^{6}$}

\author{
${ }^{1}$ Project financed by FAPESP. \\ 2 Instituto Federal do Mato Grosso, Campus Campo Novo do Parecis/MT, Brazil \\ ${ }^{3}$ UNESP/FCA, Campus Botucatu/SP, Brazil. \\ ${ }^{4}$ UNESP/FMVZ, Campus Botucatu/SP, Brazil. \\ ${ }^{5}$ Departamento de Zootecnia, ESALQ/USP, Piracicaba/SP, Brazil. \\ ${ }^{6}$ Instituto Federal do Mato Grosso, Campus Cuiabá - Bela Vista /MT, Brazil.
}

ABSTRACT - The objective of this study was to evaluate the effect of addition of different levels of cottonseed $(0,14.35,27.51$ and $34.09 \mathrm{~kg} / 100 \mathrm{~kg})$ in the diet of Nellore steers on the meat characteristics. Thirty-six steers (average initial body weight of 333.50 and average age of 20 months) were kept in feedlot stalls for 94 days, each stall with three animals. The experiment was a completely randomized design with four treatments and nine replications. The values of protein, fixed mineral residue, shear force, lipid oxidation, meat color and fat color were similar among the treatments. The increase of the cottonseed levels in the diet reduced the amount of intramuscular fat and increased the moisture content in the meat linearly. Meat aroma and flavor were negatively influenced when cottonseed addition was greater than 27.51 and $34.09 \mathrm{~kg} / 100 \mathrm{~kg}$ of the diet, respectively. Cottonseed diet did not modify the concentration of conjugated linoleic acid, saturated fatty acids or total unsaturated fatty acids, but linearly reduced the concentration of monounsaturated fatty acids in the meat.

Key Words: aroma, color, conjugated linoleic acid, flavor, lipid oxidation, shear force

\section{Introduction}

In recent years, consumers have been increasingly interested in foods that can provide beneficial substances to their health, besides having desirable nutritional characteristics. Therefore, the food industry and research centers seek foods of this nature (Oliveira et al., 2008).

Products from ruminants are also part of this group because milk as well as meat and the fat tissue contain conjugated linoleic acid, a proven carcinogenic fatty acid (Bauman \& Griinari, 2000).

Oilseeds and oils are added to beef cattle diet to increase the content of beneficial fatty acids in the meat to provide healthier meat to consumers; one example is conjugated linoleic acid (Mir et al., 2003; Sackmann et al., 2003; Gibb et al., 2004). Mir et al. (2008) observed that sunflower oil supplementation in diets for steers increased the content of conjugated linoleic acid and trans isomers in meat. However, Hristov et al. (2005) showed that sunflower oil supplementation in finishing diets changed ruminal biohydrogenation of polyunsaturated fatty acids without affecting the concentrations of conjugated linoleic acid in the meat.

Among the oilseeds, whole cottonseed is an excellent option for feedlot because the association of high protein content with high energy content makes the formulation of low cost diets easy (Medeiros et al., 2005; Cranston et al., 2006). Another advantage of cottonseed utilization in beef cattle diets is the production of more unsaturated profile of fat in the meat (Huerta-leidenz et al., 1991; Medeiros et al., 2005). However, one of the limitations of cottonseed is its association with problems in meat flavor.

The objective of this study was to verify the effect of addition of different levels of cottonseed $(0,14.35,27.51$ and $34.09 \mathrm{~kg} / 100 \mathrm{~kg}$ ) in the diet of Nellore steers on the meat characteristics of Nellore steers finished in feedlot.

\section{Material and Methods}

The experiment was carried out on Mateirinha Ranch, located in the municipality of Guiratinga, Mato Grosso State, Brazil, latitude $16^{\circ} 20^{\prime} 58^{\prime \prime} \mathrm{S}$ and longitude $53^{\circ} 45^{\prime} 30^{\prime \prime} \mathrm{W}$, average altitude of $510 \mathrm{~m}$. The region is characterized by hot and wet season generally from October to April, followed by another cold and dry season, from May to September. The climate of the region is classified as AW (wet tropical savanna with dry winter and rainy summer) according to the Köppen climate classification (1938).

Thirty-six Nellore steers, average age of 20 months and average initial body weight of $333.5 \pm 14.7 \mathrm{~kg}$ were utilized. 
The animals were identified, vaccinated and subjected to parasite control before the experimental period.

Steers were distributed equally in four treatments which corresponded to the diets with increasing amounts of cottonseed as follows: $0.00,14.35,27.51$ and $34.09 \mathrm{~kg} / 100 \mathrm{~kg}$ of whole cottonseed in relation to dietary dry matter (DM).

The animals were kept in $120 \mathrm{~m}^{2}$ feedlot stalls for 94 days, including 14 days of adaptation to diets and handling. The feedlot consisted of 12 uncovered stalls with sand floor and each stall had a feed bunker and a drinker; the animals had water ad libitum.

The formulation of isoprotein diets was based on the NRC (1996) for non-castrated growing animals and presented the same concentrate:roughage ratio (50:50). The diets were provided three times a day $(06 \mathrm{~h} 00,13 \mathrm{~h} 00$ and 17h00) in a complete diet system, allowing surplus of approximately $5 \mathrm{~kg}$ for each $100 \mathrm{~kg}$ of provided feed. Sugarcane was used as roughage associated with urea, ground corn grain, whole cottonseed and soybean meal (Table 1).

During the experimental period, the animals were weighed twice a month, after being feed-deprived for 8 hours, to monitor daily weight gain, obtained by the difference between the initial and final body weight divided by the number of days of the period. Once a month, during five consecutive days, the feed supplied and the surplus in the bunker were weighed daily. Samples of surplus were collected to quantify DM intake in each treatment. The diet adjustments were based on the amount of surplus and the daily weight gain.

Table 1 - Proportion of ingredients of experimental diets on a dry matter basis and percentage of dry matter, crude protein and ether extract of treatments

\begin{tabular}{lcccc}
\hline \multirow{2}{*}{ Ingredients $(\mathrm{kg} / 100 \mathrm{~kg})$} & \multicolumn{4}{c}{ Whole cottonseed in diet $(\mathrm{kg} / 100 \mathrm{~kg})$} \\
\cline { 2 - 5 } & 0 & 14.35 & 27.51 & 34.09 \\
\hline Sugarcane & 50.00 & 50.00 & 50.00 & 50.00 \\
Whole cottonseed & 0.00 & 14.35 & 27.51 & 34.09 \\
Ground corn grain & 28.13 & 18.68 & 10.19 & 6.01 \\
Soybean meal & 19.47 & 14.57 & 9.90 & 7.50 \\
Urea & 1.20 & 1.20 & 1.20 & 1.20 \\
Mineral mixture & 0.84 & 0.84 & 0.84 & 0.84 \\
NaCl & 0.36 & 0.36 & 0.36 & 0.36 \\
\hline Total & 100.0 & 100.0 & 100.0 & 100.0 \\
\hline Dry matter $^{2}$ & 59.35 & 59.85 & 60.30 & 60.53 \\
Crude protein $^{2}$ & 14.11 & 14.17 & 14.16 & 14.13 \\
Ether extract $^{2}$ & 2.99 & 4.98 & 6.81 & 7.73 \\
Neutral detergent fiber $^{3}$ & 35.17 & 39.63 & 43.70 & 45.73 \\
Acid detergent fiber $^{3}$ & 23.33 & 26.33 & 29.06 & 30.42 \\
Total digestible nutrients $^{4}$ & 71.76 & 71.27 & 70.84 & 70.63 \\
\hline
\end{tabular}

${ }^{1}$ Composition/kg: P - 136.80 g; Ca - 205.00 g; Mg - 11.00 g; S - 21.23 g; Zn - 10.50 g;

$\mathrm{Cu}-3.75 \mathrm{~g} ; \mathrm{Mn}-1.50 \mathrm{~g} ; \mathrm{Fe}-4.50 \mathrm{~g}$; Co $-0.20 \mathrm{~g}$; I - $0.30 \mathrm{~g}$ e Se - $28.82 \mathrm{mg}$.

${ }^{2}$ Determined by the method described by Silva \& Queiroz (2002).

${ }^{3}$ Determined by the method described by Van Soest et al. (1991).

${ }^{4}$ Values estimated according to the NRC (2001).
The average final body weight of the animals after 94-day feedlot was $446.6 \pm 28.0 \mathrm{~kg}$. The steers were transported to Sadia slaughterhouse in the city of Várzea Grande, Mato Grosso State, Brazil, $345 \mathrm{~km}$ away from Mateirinha Ranch. The animals were slaughtered by stunning and jugular cutting after a 24-hour feed deprivation. After exsanguination, skinning and evisceration, the carcass were identified, washed, weighed and chilled at $7{ }^{\circ} \mathrm{C}$ for 24 hours. From the left half-carcass of each animal, sirloin steaks were taken from the area of the 12th thoracic vertebrae, 3rd lumbar vertebrae, individually packaged in identified plastic bags and frozen at $-18{ }^{\circ} \mathrm{C}$.

A $2.5 \mathrm{~cm}$ transversal sirloin sample, taken from each animal, from the 12th thoracic vertebrae, was utilized to determine shear force. According to the method described by Savell et al. (1998), samples were cooked until reaching internal temperature of $71^{\circ} \mathrm{C}$, cut into $1.27^{\circ} \mathrm{cm}$ cylinders, chilled (at $4^{\circ} \mathrm{C}$ for 12 hours) and evaluated in a texture meter, model TA-XT 2i, Stable Micro System (UK) equipped with a set of Warner-Bratzler blades. Eight evaluations were performed on each sample.

The colorimetric system, which indicates color differences corresponding to the human sensitivity, was used to determine meat and fat color. A $2.5 \mathrm{~cm}$ transversal sirloin sample of each animal, from the 13th thoracic vertebrae, was thawed for 24 hours until the temperature of $4{ }^{\circ} \mathrm{C}$ and exposed to atmospheric air for 30 minutes; then, a reading of the surface of each sample was done using Chroma Meter. Five readings were done in different points of the sample for meat color and fat color. The evaluated parameters were $L^{*}, a^{*}$ and $b^{*}$, of the CIELab system, where $L^{*}$ represents luminosity, $a^{*}$ is the red intensity and $\mathrm{b}^{*}$, the yellow intensity.

A $2.5 \mathrm{~cm}$ wide transversal sirloin sample from each animal, from the 1st lumbar vertebrae, was used to obtain the centesimal composition and lipid oxidation. The moisture content was obtained according to the 39.1.02 method of the AOAC (2007). The Kjeldahl-micro method was utilized to determine total nitrogen utilized. Crude protein was calculated in function of the total nitrogen content, multiplied by factor 6.25 . The ether extract was determined according to the AOAC (2007), item 39.1.05. The same recommended method was used to obtain the amount of fixed mineral residue. The lipid oxidation was evaluated by the formation of substances reactive to 2-tiobarbituric acid (TBA), utilizing the method of Wyncke (1970) for meat samples under 75-day storage.

A $2.5 \mathrm{~cm}$ wide transversal sample, from the 2nd lumbar vertebrae, was used to evaluate the fatty acid profile, utilizing the method described by Hara \& Radin (1978) to extract 
lipids. The method proposed by Christie (1982), using a methanol solution of sodium metoxide, was utilized for trans esterification of fatty acids and conjugated linoleic acid.

The transmethyled samples were analyzed in a gas chromatograph model Focus CG- Finnigan, with flame ionization detector, capillary column CP-Sil 88 (Varian), with $100 \mathrm{~m}$ of length, $0.25 \mu \mathrm{m}$ of internal diameter and $0.20 \mu \mathrm{m}$ of film thickness. Hydrogen was used as carrier gas at a flow of $1.8 \mathrm{~mL} / \mathrm{min}$. For initial oven temperature program the wait time was $4 \mathrm{~min}$; for $175^{\circ} \mathrm{C}\left(13^{\circ} \mathrm{C} / \mathrm{min}\right)$, wait time was $27 \mathrm{~min}$, and for $215{ }^{\circ} \mathrm{C}\left(4^{\circ} \mathrm{C} / \mathrm{min}\right)$ wait time was $9 \mathrm{~min}$; and then it increased to $7^{\circ} \mathrm{C} / \mathrm{min}$ for $5 \mathrm{~min}$ until reaching $230{ }^{\circ} \mathrm{C}$, totalizing $65 \mathrm{~min}$. The vaporizer temperature was $250{ }^{\circ} \mathrm{C}$ and the detector was set at $300{ }^{\circ} \mathrm{C}$.

A $1 \mu \mathrm{L}$ aliquot of esterified extract was injected in the chromatographer and the identification of fatty acids was done by comparing retention times; the percentages of fatty acids were obtained through software Chromquest 4.1 (Thermo Electron, Italy).

Fatty acids were identified by comparing retention times of methyl esters of the samples with fatty acid standards. The fatty acids were quantified by the normalization of methyl ester areas.

A conjugated linoleic acid is a mixture of linoleic acid isomers. In the present study, the conjugated linoleic acid is the sum of $\mathrm{C}_{18: 2 \text { trans 11-cis 15 }}, \mathrm{C}_{18: 2 \text { cis9-cis 12, }}, \mathrm{C}_{18: 2 \text { cis 9-trans 11 }}$ and $\mathrm{C}_{18: 2 \text { trans } 10 \text { - cis 12 }}$ fatty acids. Desirable fatty acids are the sum of unsaturated fatty acids and acid $\mathrm{C}_{18: 0}$. Undesirable fatty acids are the sum of $\mathrm{C}_{14: 0}$ and $\mathrm{C}_{16: 0}$ acids (Huerta-Leidenz et al., 1991).

A $2.5 \mathrm{~cm}$ wide transversal sirloin sample from the $3 \mathrm{rd}$ lumbar vertebrae of each animal was used for the sensory analysis. Ten trained tasters performed the flavor and aroma evaluations. For the flavor analysis, the samples were salted $(100 \mathrm{~g} / \mathrm{L})$ for 60 minutes at $5{ }^{\circ} \mathrm{C}$, at a $1: 1$ ratio. Next, they were wrapped in aluminum foil and heated in a pre-heated electric griddle at $250{ }^{\circ} \mathrm{C}$ for 30 minutes. When the final internal temperature measured in the geometric center was $90{ }^{\circ} \mathrm{C}$, they were taken from the griddle. Then the samples were cut into similar size cubes and all fat and burned pieces were removed. The samples were offered to tasters in plastic plates, heated in microwave oven for 30 seconds until reaching $50{ }^{\circ} \mathrm{C}$. For the aroma analysis, the samples were completely immersed in water in a $100 \mathrm{~mL}$ beaker, and cooked in water bath for $10 \mathrm{~min}$. After, they were given to tasters in the beakers on a heated plate at $100{ }^{\circ} \mathrm{C}$.

The multiple comparison test was applied for the strange aroma intensity and strange flavor with the following scale: 1 - extremely less intense than the control; 2 - much less intense than the control; 3 - fairly less intense than the control; 4 - slightly less intense than the control; 5 - equal to control; 6 - slightly more intense than the control; 7 fairly more intense than the control; 8 - much more intense than the control; and 9 - extremely more intense than the control. The control refers to the samples from the steers that did not receive whole cottonseed addition to the diet; all the other samples from treatments with cottonseed were compared with the control.

The experiment was set in a completely randomized design with 4 treatments and 9 replications. When significant $(P>0.05)$, the effects of the treatments were estimated by regression analysis. For the statistical analysis, PROC MIXED of SAS (Statistical Analysis System, version 8.0) was utilized.

\section{Results and Discussion}

There was no difference $(\mathrm{P}>0.05)$ among the treatments for the content of protein and fixed mineral residue in meat (Table 2). The increase of cottonseed in the diet reduced $(\mathrm{P}<0.05)$ the concentration of intramuscular fat linearly and increased $(\mathrm{P}<0.05)$ the moisture content linearly. This occurred because polyunsaturated fats represent the main components of ether extract found in cottonseed and do not undergo ruminal fermentation for the production of volatile fatty acids, inhibiting the growth of ruminal microbiota and affecting the synthesis and flow of microbial protein to the abomasum, which probably slowed down muscle development (Owens et al., 1995). It was concluded that the developmental pace of steers fed greater contents of cottonseed was depressed due to the smaller concentration of intramuscular fat in meat. However, Madruga et al. (2008), when using $0,20,30$ and $40 \%$ of cottonseed in the diet of sheep, did not find any difference among the treatments for meat centesimal composition.

There was no difference $(\mathrm{P}>0.05)$ for shear force among the treatments. Similarly, a lipid-rich diet with flaxseed did not interfere in tenderness or succulence of meat from steers (Labrune et al., 2008). However, the addition of frying oil in the diet of steers promoted a more tender meat (Nelson et al., 2008).

There is evidence that a high value of shear force is a characteristic of Bos taurus indicus (Shackelford et al., 1994) cattle and that the increasing participation of zebu genes (Bos taurus indicus) in the genotype results in harder meat (Sherbeck et al., 1996). However, other factors influence the texture, such as the feedlot time and feed composition. Junqueira (1996), for example, verified shear force value of 4.6 and $4.0 \mathrm{~kg}$, respectively, on the $3 \mathrm{rd}$ and 14 th day after slaughter in the meat from young $1 \frac{1}{2}$ Marchigian $\times 1 / 2$ Nellore 
cattle fed $60 \%$ of concentrate and $40 \%$ of oat hay for 182 days.

Lipid oxidation is a change that may occur during the processing, distribution and preparation of meat, causing other changes in the food and altering the nutritional quality, color, flavor, aroma and texture (Shahidi \& Wanansundara, 1992). The meat with abundant unsaturated fat is more susceptible to oxidation and has been associated with unpleasant flavor (Mottram, 1998).

We observe that the values of substances reactive to 2-thiobarbituric acid were similar $(\mathrm{P}>0.05)$ among the treatments. Therefore, it was not confirmed thad lipid oxidation aggravation is related to supplementing cattle with cottonseed. Thus, it is unnecessary to utilize antioxidants in the diet of steers fed cottonseed. Similarly, the addition of frying oil did not interfere in meat shelf life (Nelson et al., 2008).

Color is one of the main attributes of meat that most affects the amount and chemical state of the principal pigment, myoglobin (Felício, 1999), so the higher the concentration, the darker the meat. Consumers discriminate dark meat because they associate it with more mature animals, and consequently, with greater meat toughness (Sainz, 1996). Older animals and the ones that exercise intensively have darker color meat (Felício, 1999). Young bull meat is darker than the meat from male and female calves (Purchas et al., 1990).

Analyzing meat color (Table 2), we can observe that luminosity $\left(\mathrm{L}^{*}\right)$ ranged from 32.758 to 33.611 ; the red intensity varied from 13.967 to 14.598 ; and yellow intensity from -0.226 to 0.071 . The average $L^{*}$ was 32.85 , which is similar to the average related by Rodrigues \& Andrade (2004). There was no change $(P>0.05)$ of luminosity, red intensity and yellow intensity when cottonseed was utilized in the diet. This possible similarity may be related to the similar ages of animals and the same feedlot regimen. Costa et al. (2008), studying the meat color of castrated Nellore calves, slaughtered at 36 and 48 months of age, found similar values of luminosity.

The results (Table 3) for luminosity, red intensity and yellow intensity of fat were similar $(\mathrm{P}>0.05)$ among the treatments. Cattle fat color depends on age, gender and breed. Diet is a more extrinsic factor, but it depends on the feed time (Dunne et al., 2009). Color variation of cattle fat is a result of carotenoid accumulation that makes it yellowish (Felício, 1999). Cattle raised on pasture generally have darker yellow fat than animals raised in intensive systems with high levels of concentrate because of carotenoids present in the forage (Dunne et al., 2009). A consumer usually rejects yellow fat and prefers the white one, although there are no problems nutritionally, but the yellow intensity is usually associated with older animals (Felício, 1999).

The appearance of cattle fat is mainly affected by the absorbance of carotene and derivatives of hemoglobin, reflectance, transmittance, fat fluorescence, reflectance and fluorescence of non-lipid components such as connective tissue and cell membranes (Irie, 2001). The similarity of

Table 2 - Meat characteristics of Nellore steers according to cottonseed levels in diet

\begin{tabular}{|c|c|c|c|c|c|c|c|}
\hline \multirow{2}{*}{ Item } & \multicolumn{4}{|c|}{ Cottonseed in diet $(\mathrm{kg} / 100 \mathrm{~kg})$} & \multirow{2}{*}{$\begin{array}{l}\text { Standard } \\
\text { deviation }\end{array}$} & \multicolumn{2}{|c|}{ P-value } \\
\hline & 0 & 14.35 & 27.51 & 34.09 & & Linear & Quadratic \\
\hline Moisture $(\mathrm{g} / 100 \mathrm{~g})^{1}$ & 74.73 & 75.14 & 75.18 & 75.27 & 0.47 & 0.013 & 0.367 \\
\hline Protein $(\mathrm{g} / 100 \mathrm{~g})$ & 22.79 & 22.80 & 22.81 & 22.81 & 0.40 & 0.897 & 0.987 \\
\hline Intramuscular fat $(\mathrm{g} / 100 \mathrm{~g})^{2}$ & 1.42 & 1.01 & 0.97 & 0.90 & 0.26 & 0.001 & 0.010 \\
\hline Fixed mineral residue (g/100 g) & 1.02 & 1.00 & 1.00 & 0.99 & 0.07 & 0.417 & 0.980 \\
\hline Shear force (kg) & 4.50 & 4.38 & 4.93 & 4.76 & 0.67 & 0.161 & 0.620 \\
\hline SRTBA & 0.013 & 0.014 & 0.014 & 0.012 & 0.01 & 0.962 & 0.586 \\
\hline Luminosity & 32.611 & 33.165 & 32.874 & 32.758 & 2.04 & 0.923 & 0.592 \\
\hline Red intensity & 14.192 & 14.352 & 13.967 & 14.598 & 1.24 & 0.773 & 0.756 \\
\hline Yellow intensity & -0.014 & -0.063 & -0.226 & 0.071 & 1.44 & 0.977 & 0.806 \\
\hline
\end{tabular}

SRTBA - substances reactive to 2-tiobarbituric acid (mg of malonaldehyde/ kg of sample).

${ }^{1} \hat{\mathrm{Y}}=0.01479 \mathrm{x}+74.80\left(\mathrm{r}^{2}=0.86\right)$.

${ }^{2} \hat{\mathrm{Y}}=-0.014 \mathrm{x}+1.353+0.005\left(\mathrm{r}^{2}=0.842\right)$.

Table 3 - Fat color of Nellore steers according to cottonseed levels in diets

\begin{tabular}{|c|c|c|c|c|c|c|c|}
\hline \multirow{2}{*}{ Item } & \multicolumn{4}{|c|}{ Cottonseed in the diet $(\mathrm{kg} / 100 \mathrm{~kg})$} & \multirow{2}{*}{$\begin{array}{r}\text { Standard } \\
\text { deviation }\end{array}$} & \multicolumn{2}{|c|}{ P-value } \\
\hline & 0 & 14. 35 & 27.51 & 34.09 & & Linear & Quadratic \\
\hline Luminosity & 61.84 & 62.84 & 61.86 & 63.00 & 2.22 & 0.530 & 0.839 \\
\hline Red intensity & 7.35 & 7.40 & 8.08 & 8.23 & 1.56 & 0.170 & 0.677 \\
\hline Yellow intensity & 8.50 & 7.95 & 7.53 & 8.08 & 1.13 & 0.159 & 0.227 \\
\hline
\end{tabular}


the breeding system and the calf ages may possibly be the reason why there was so difference among the treatments for luminosity, red intensity and yellow intensity of fat. The results of luminosity are similar to the ones obtained by Rodrigues \& Andrade (2004) and Costa et al. (2008).

Butyric $\left(\mathrm{C}_{4: 0}\right)$, caproic $\left(\mathrm{C}_{6: 0}\right)$ and caprylic $\left(\mathrm{C}_{8: 0}\right)$ fatty acids were not detected in any treatment. It was possible to verify that oleic $\left(\mathrm{C}_{18: 1 \text { cis } 9}\right)$ fatty acid had the greatest concentration, followed by palmitic $\left(\mathrm{C}_{16: 0}\right)$ and stearic $\left(\mathrm{C}_{18: 0}\right)$ fatty acids (Table 4$)$. These results are similar to the ones reported by Silva et al. (2006) and Silva et al. (2009).

The concentration of lauroleic $\left(\mathrm{C}_{12: 1}\right)$, capric $\left(\mathrm{C}_{10: 0}\right)$, lauric $\left(\mathrm{C}_{12: 0}\right)$, undecanoic $\left(\mathrm{C}_{11: 0}\right)$, decenoic $\left(\mathrm{C}_{10: 1}\right)$ and pentadecanoic $\left(\mathrm{C}_{15: 0}\right)$ acids was not altered $(\mathrm{P}>0.05)$ by cottonseed diet. Madruga et al. (2008) did not find a difference among the treatments for the content of $\mathrm{C}_{10: 0}$ and $\mathrm{C}_{12: 0}$ utilizing 0,20,30 and 40\% of cottonseed in the diet of sheep. Mir et al. (2008) did not verify a difference in the content of $\mathrm{C}_{15: 0}$ when adding $15 \%$ of sunflower seed oil in the diet of finishing cattle.

With the addition of cottonseed in the diet, the contents of iso-tridecanoic $\left(\mathrm{C}_{13: 0}{ }_{\text {Iso }}\right)$, anteiso-tridecanoic $\left(\mathrm{C}_{13: 0}\right.$ ANTEISO $)$, iso-pentadecanoic $\left(\mathrm{C}_{15: 0 \text { ISO }}\right)$, anteiso-pentadecanoic $\left(\mathrm{C}_{\text {15:0 ANTEIso }}\right)$ and iso-heptadecanoic $\left(\mathrm{C}_{\text {17:0 Iso }}\right)$ fatty acids increased linearly $(\mathrm{P}<0.05)$. However, reduction $(\mathrm{P}<0.05)$ of myristoleic $\left(\mathrm{C}_{14: 1 \text { cis } 9}\right)$, palmitoleic $\left(\mathrm{C}_{16: 1 \text { cis } 9}\right)$ and margaric $\left(C_{17: 0}\right)$ acids is verified. According to Silva et al. (2009), the addition of $15 \%$ of sunflower seed in the diet of finishing cattle did not change the concentration of $\mathrm{C}_{14: 1 \text { cis } 9}$ acid, but resulted in a smaller content of $\mathrm{C}_{16: 1 \text { cis } 9}$. Mir et al. (2008) verified decrease in the content of $\mathrm{C}_{17: 0}$ when sunflower seed was included in the cattle diet.

The lipid-rich diet did not change $(\mathrm{P}>0.05)$ the content of myristic $\left(\mathrm{C}_{14: 0}\right), \mathrm{C}_{16: 0}$ and iso-hexadecanoic $\left(\mathrm{C}_{16: 0 \text { Iso }}\right)$ fatty acids, but there was a linear increase $(\mathrm{P}<0.05)$ of the content of iso-tetradecanoic $\left(\mathrm{C}_{14: 0 \text { ISO }}\right)$. Felton \& Kerley (2004) verified that the meat from animals that were fed diets with great content of lipids had smaller concentrations of $\mathrm{C}_{14: 0}$ and $\mathrm{C}_{16: 0}$.

The increase in the amount of cottonseed in the diet decreased $(\mathrm{P}<0.05)$ the concentration of heptadecenoic $\left(\mathrm{C}_{17: 1}\right)$ acid. Silva et al. (2009) also verified a reduction of the content of $\mathrm{C}_{17: 1}$ in the meat from Nellore calves that received diets with protected fats.

The increase of cottonseed in the $\operatorname{diet}(\mathrm{P}<0.05)$ elevated the concentration of $\mathrm{C}_{18: 0}$ linearly because $\mathrm{C}_{18: 0}$ is abundant in cottonseed. It is important to point out that $\mathrm{C}_{18: 0}$, unlike other saturated fatty acids, acts on the reduction of serum cholesterol in humans (Bonanome \& Grundy, 1988). This reduction promoted by $\mathrm{C}_{18: 0}$ can be explained by the decrease of the cholesterol absorption and increase of endogenous cholesterol excretion (Schneider et al., 2000). Preston et al. (1989) observed that the concentration of $\mathrm{C}_{18: 0}$ in meat fat was also increased with the addition of cottonseed to the cattle diet.

The inclusion of cottonseed in the diet did not influence $(\mathrm{P}>0.05)$ the concentration of most isomers of octadecenoic acid $\left(\mathrm{C}_{18: 1}\right)$ e.g.: $\mathrm{C}_{18: 1 \text { trans } 6 \text { - trans } 9}, \mathrm{C}_{18: 1 \text { trans 12 }}, \mathrm{C}_{18: 1 \text { cis 11 }}, \mathrm{C}_{18: 1}$ cis 12 $, \mathrm{C}_{18: 1 \text { cis 13 }}, \mathrm{C}_{18: 1 \text { trans 16 }}$ and $\mathrm{C}_{18: 1 \text { cis 15 }}$. However, for the content of fatty acid $\mathrm{C}_{18: 1 \text { trans } 10 \text { - trans } 11}$ there was an increase $(\mathrm{P}<0.05)$, whereas there was a reduction $(\mathrm{P}<0.05)$ for the concentration of oleic acid $\left(\mathrm{C}_{18: 1 \text { cis } 9}\right)$. The results indicate that cottonseed also keeps a favorable biohydrogenation route to $\mathrm{C}_{18: 1 \text { trans 10-trans 11 }}$ accumulation as the main fatty acid $\mathrm{C}_{18: 1 \text { trans }}$ in the rumen. The content of $\mathrm{C}_{18: 1}$ acid in buffalo meat was not modified by the inclusion of soybean in the diet but there was an increase of vaccenic acid concentration (Oliveira et al., 2008). Mir et al. (2008) obtained a reduction of $\mathrm{C}_{18: 1 \text { cis } 9}$ and $\mathrm{C}_{18: 1 \text { cis 11 }}$ concentration.

The cottonseed-rich diet, that is, rich in unsaturated lipids, did not modify $(\mathrm{P}>0.05)$ the content of $\gamma$-linolenic $\left(\mathrm{C}_{18: 3 \mathrm{n} 6}\right)$ and $\alpha$-linolenic $\left(\mathrm{C}_{18: 3 \mathrm{n} 3}\right)$. Similarly, in the experiment of Huerta-Leidenz et al. (1991), the concentration of $\mathrm{C}_{18: 3}$ did not follow the addition of cottonseed in the cattle diet.

Linolenic fatty acid $\left(\mathrm{C}_{18: 3}\right)$ is considered essential because it is a synthesis precursor of polyunsaturated fatty acids that have special nutritional properties (Bressan et al., 2004). Among the acids commonly present in animal fat are linoleic acid $\left(\mathrm{C}_{18: 2}\right)$ and arachidonic acid $\left(\mathrm{C}_{20: 4}\right)$, which are essential compounds for humans (Rice, 1984). Although polyunsaturated fatty acids are mostly not essential, they have an important role to reduce serum cholesterol (Bressan et al., 2004).

This information is confirmed by other authors in the literature, who reported low occurrence of heart diseases, although there was a high intake of fats in Mediterranean countries where there is a diffuse use of olive oil and similar products that provide substantial absorption of fatty acids, especially oleic acid (Wood et al., 1999). As a result of this olive-oil rich diet, the occurrence of serum cholesterol reduction in humans was verified and can be compared to low-fat diets (Wood et al., 1999).

There was no difference $(\mathrm{P}>0.05)$ among the treatments for the content of behenic $\left(\mathrm{C}_{22: 0}\right)$ and lignoceric $\left(\mathrm{C}_{24: 0}\right)$ fatty acids. Madruga et al. (2008) did not find influence of the cottonseed increase to sheep diet on the percentage of $\mathrm{C}_{22: 0}$. Silva et al. (2009) verified the increase of $\mathrm{C}_{22: 0}$ concentrations and the reduction of $\mathrm{C}_{24: 0}$ content in the meat from calves that received protected-fat diet.

The percentage of erucic $\left(\mathrm{C}_{22: 1}\right)$, nervonic $\left(\mathrm{C}_{24: 1}\right)$, gadoleic $\left(\mathrm{C}_{20: 1}\right)$, eicosatrienoic $\left(\mathrm{C}_{20: 3}\right)$, arachidonic 
Table 4 - Fatty acid profile of the meat from Nellore steers according to cottonseed levels in the diets

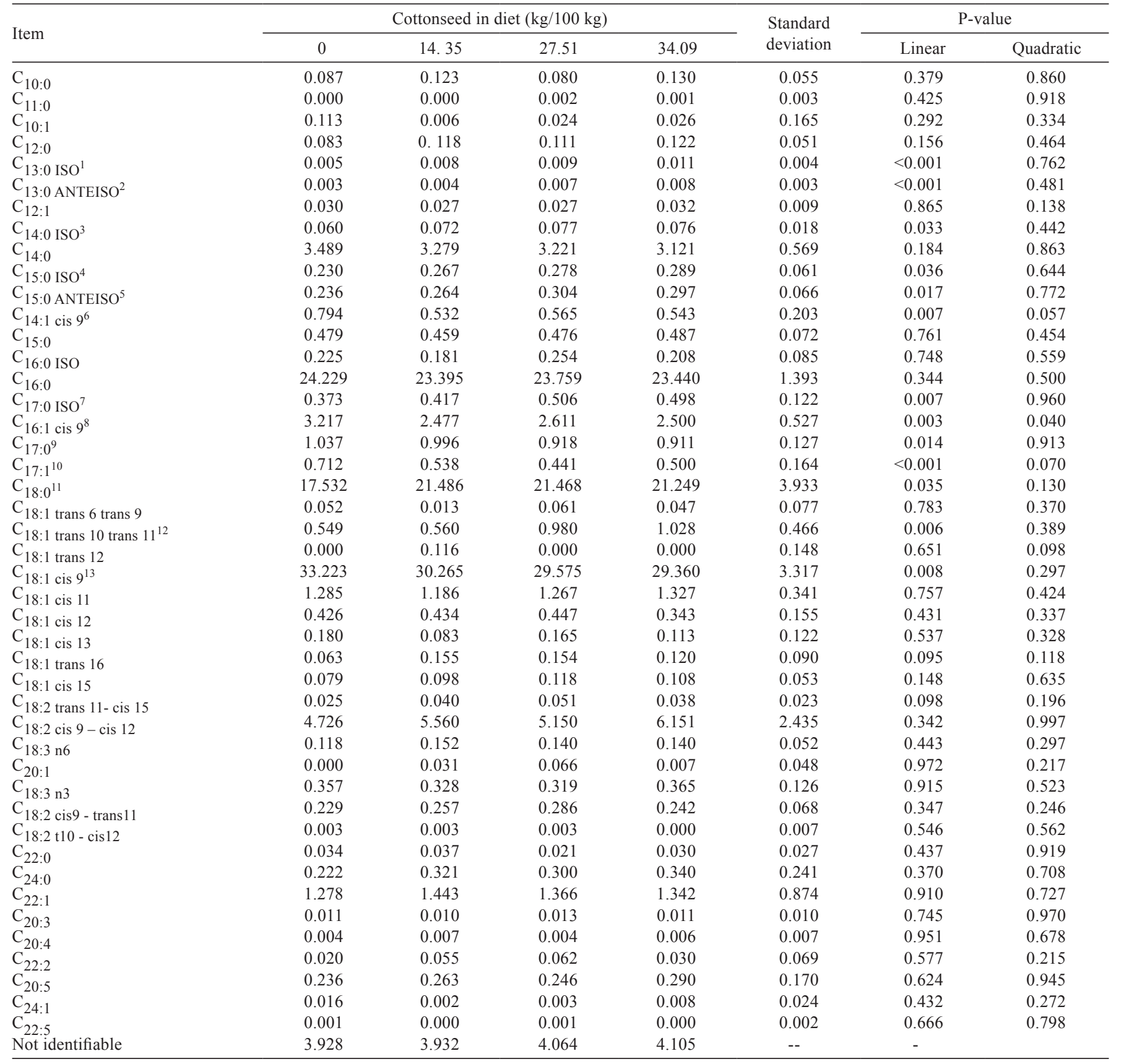

${ }^{1} \hat{Y}=0.000209 x+0.005\left(r^{2}=0.958\right)$.

${ }^{2} \hat{Y}=0.000139 x+0.002\left(r^{2}=0.949\right)$.

${ }^{3} \hat{\mathrm{Y}}=0.0004964 \mathrm{x}+0.06175\left(\mathrm{r}^{2}=0.88\right)$.

${ }^{4} \hat{Y}=0.00416 x+0.3706\left(r^{2}=0.428\right)$.

${ }^{5} \hat{Y}=0.002015 x+0.2376\left(r^{2}=0.92\right)$.

${ }^{6} \hat{Y}=-0.006 x+0.734\left(r^{2}=0.646\right)$.

${ }^{7} \hat{Y}=0.004 x+0.370\left(r^{2}=0.933\right)$.

${ }^{8} \hat{Y}=-0.018 x+3.050\left(r^{2}=0.633\right)$.

${ }^{9} \hat{\mathrm{Y}}=-0.003997 \mathrm{x}+1.104\left(\mathrm{r}^{2}=0.96\right)$.

${ }^{10} \hat{Y}=-0.006 x+0.678\left(r^{2}=0.795\right)$

${ }^{11} \hat{\mathrm{Y}}=0.1043 \mathrm{x}+18.48\left(\mathrm{r}^{2}=0.65\right)$.

${ }^{12} \hat{\mathrm{Y}}=0.015 \mathrm{x}+0.477\left(\mathrm{r}^{2}=0.849\right)$.

${ }^{13} \hat{Y}=-0.110 x+32.71\left(r^{2}=0.876\right)$. 
$\left(\mathrm{C}_{20: 4}\right)$, eicosapentaenoic $\left(\mathrm{C}_{20: 5}\right)$, docosadienoic $\left(\mathrm{C}_{22: 2}\right)$ and docosapentanoic $\left(\mathrm{C}_{22: 5}\right)$ fatty acids was not changed ( $P>0.05)$ by the test diet. Similarly, Silva et al. (2009) verified that the concentration of $\mathrm{C}_{24: 1}, \mathrm{C}_{20: 1}, \mathrm{C}_{20: 3}$ and $\mathrm{C}_{22: 2}$ acids were not altered by the lipid-rich diet. Oliveira et al. (2008) observed an increase in the percentage of $\mathrm{C}_{20: 4}$ in the meat from buffalo fed soybean.

There was no difference $(\mathrm{P}>0.05)$ among the treatments for the percentage of evaluated isomers of octadecadenoic acid $\left(\mathrm{C}_{\text {18:2 }}\right)$ e.g.: $\mathrm{C}_{18: 2 \text { trans 11-cis 15 }}, \mathrm{C}_{\text {18:2 cis9-cis 12, }}, \mathrm{C}_{18: 2 \text { cis9-trans 11 }}$ and $\mathrm{C}_{18: 2}$ trans 10 - cis 12. Thus, the amount of $\mathrm{C}_{18: 2}$ was not changed by the diet test, although the amount of this fatty acid is greater in cottonseed. This shows that unsaturated fatty acids in cottonseed are not totally protected in ruminal degradation, contradicting the reports of Baldwin \& Allison (1983) that suggest that seed oils are protected from ruminal degradation. Nelson et al. (2008) report lower content of palmitoleic and oleic acids with the addition of frying oil in the diet and higher concentration of linoleic and vaccenic acids.

The content of conjugated linoleic acid was not changed $(\mathrm{P}>0.05)$ by the cottonseed diet (Table 5). This can be explained by the slow release of triglycerides in the grain, which allowed normal ruminal biohydrogenation by microorganisms. Oliveira et al. (2008), when increasing the lipid content of ration through the addition of whole soybean grain, did not observe the increase of conjugated linoleic acid concentration. However, the addition of $15 \%$ of sunflower seed in the diet of finishing sheep increased the percentage of conjugated linoleic acid in the meat (Bolte et al., 2002), suggesting that cottonseed and soybean grain in the rumen may have a different behavior from sunflower seed.

Nevertheless, some authors report that the addition of oil in the diet increases the amount of conjugated linoleic acid in the meat from ruminants. For example, in the experiment of Mir et al. (2004), the concentration of conjugated linoleic acid of cattle meat was quadruplicated after animals received with sunflower. A similar result was observed with the inclusion of soybean oil in the diet that increased the content of conjugated linoleic acid in the meat (Oliveira et al., 2008). The percentage of conjugated linoleic acid of cattle meat was increased with the addition of frying oil to the diet (Nelson et al., 2008). Possibly, in these cases, the presence of unsaturated fatty acids from the vegetable oil induced ruminal microorganisms to perform the biohydrogenation process because the existence of double bonds causes negative effects on the microbial population. During the breaking process of double bonds and consequent hydrogen addition, there is the formation of intermediate compounds, among them the conjugated linoleic acid (Jenkins \& McGuire, 2006). Because unsaturated fatty acids are completely and rapidly available in the rumen, it is possible to state that the capacity of microorganisms to completely saturate the volume of linoleic acids may have been exceeded, making intermediate fatty acids from biohydrogenation reactions go to the intestines; that caused the increase of conjugated linoleic acid concentration (Oliveira et al., 2008).

The amount of saturated and undesirable fatty acids was not changed $(\mathrm{P}>0.05)$ by the cottonseed diet. Likewise, Huerta-Leidenz et al. (1991) did not find a difference for saturated fatty acid content between the treatments with and without cottonseed. Madruga et al. (2008) did not observe a change in the composition of saturated fatty acids in the meat from sheep cottonseed.

Contrary to the results found by Huerta-Leidenz et al. (1991), there was a reduction $(\mathrm{P}<0.05)$ of monounsaturated fatty acids in the meat from steers fed cottonseed. Gillis et al. (2004) reported lower concentration of monounsaturated fatty acids in the meat from calves fed lipid-rich diets. There

Table 5 - Proportions of fatty acids, strange aroma intensity and strange flavor intensity of the meat of Nellore steers according to cottonseed levels in the diets

\begin{tabular}{|c|c|c|c|c|c|c|c|}
\hline \multirow{2}{*}{ Item } & \multicolumn{4}{|c|}{ Cottonseed in diet $(\mathrm{kg} / 100 \mathrm{~kg})$} & \multirow{2}{*}{$\begin{array}{l}\text { Standard } \\
\text { deviation }\end{array}$} & \multicolumn{2}{|c|}{ P-value } \\
\hline & 0 & 14.35 & 27.51 & 34.09 & & Linear & Quadratic \\
\hline CLA (g/100 g) & 4.98 & 5.84 & 5.49 & 6.43 & 2.41 & 0.318 & 0.960 \\
\hline SFA (g/100 g) & 48.32 & 51.42 & 51.79 & 51.22 & 4.72 & 0.960 & 0.314 \\
\hline $\operatorname{MUFA}(\mathrm{g} / 100 \mathrm{~g})^{1}$ & 42.02 & 37.95 & 37.81 & 37.40 & 3.48 & 0.003 & 0.118 \\
\hline PUFA (g/100 g) & 5.73 & 6.67 & 6.3 & 7.27 & 2.66 & 0.332 & 0.949 \\
\hline UFA (g/100 g) & 47.75 & 44.62 & 44.11 & 44.67 & 3.79 & 0.057 & 0.205 \\
\hline DFA $(g / 100 g)$ & 65.28 & 66.11 & 65.58 & 65.92 & 1.89 & 0.273 & 0.583 \\
\hline OFA (g/100 g) & 27.72 & 26.67 & 26.98 & 26.56 & 1.75 & 0.607 & 0.568 \\
\hline Aroma & 5.00 & 5.01 & 5.51 & 5.99 & 0.45 & 0.122 & $<0.001$ \\
\hline Flavor & 5.00 & 5.02 & 5.13 & 5.99 & 0.45 & 0.230 & $<0.001$ \\
\hline
\end{tabular}

CLA - conjugated linoleic acid; SFA - saturated fatty acids; MUFA - monounsaturated fatty acids; PUFA - polyunsaturated fatty acids; UFA - total unsaturated fatty acids; DFA - desirable fatty acids (UFA $\left.+\mathrm{C}_{18: 0}\right)$; OFA - undesirable fatty acids $\left(\mathrm{C}_{14: 0}+\mathrm{C}_{16: 0}\right)$; aroma - strange aroma intensity; flavor - strange flavor intensity.

${ }^{1} \hat{Y}=-0.127 x+41.20\left(r^{2}=0.786\right)$. 
was no alteration $(\mathrm{P}>0.05)$ in the content of polyunsaturated fatty acids, and the experimental diet also had no influence $(\mathrm{P}>0.05)$ on the amount of total unsaturated fatty acids. The percentage of desirable fatty acids was not modified either $(\mathrm{P}>0.05)$. Madruga et al. (2008) did not notice the change in the percentage of monounsaturated, polyunsaturated, total unsaturated and desirable fatty acids in the meat from sheep fed cottonseed. Felton \& Kerley (2004) did not observe alterations in the concentration of monounsaturated, polyunsaturated and saturated fatty acids in the meat from animals that did not receive diets with greater amounts of lipids.

Regarding the sensorial analysis (Table 5), it is verified that the cottonseed addition over $34.09 \mathrm{~kg}$ for every $100 \mathrm{~kg}$ of the diet $(\mathrm{P}<0.05)$ resulted in slightly more intense strange flavor. This result is in accordance with the ones found by Pesce (2008), who did not find any alteration in the flavor of meat from cattle fed up to $20 \%$ of cottonseed in the diet when studying the cottonseed influence in meat attributes.

Concerning meat flavor, the addition of cottonseed over $27.51 \mathrm{~kg} / 100 \mathrm{~kg}$ of the diet of Nellore cattle caused $(\mathrm{P}<0.05)$ a slightly more intense strange aroma than the control. Similarly, Pesce (2008) did not verify strange aroma in the meat from cattle supplemented with up to $20 \%$ of cottonseed in the diet.

Wood et al. (2003) verified that the muscles with high levels of $\mathrm{C}_{18: 2}$ oxidate quickly when heated, producing several volatile compounds, including pentanal and hexanal aldehydes, which affected the aromatic quality of the meat. However, the content of $\mathrm{C}_{18: 2}$ seems not to be the reason for the alteration of the meat flavor and aroma when the diet with cottonseed did not increase the concentration of $\mathrm{C}_{18: 2}$, even though $\mathrm{C}_{18: 2}$ corresponds to more than $50 \%$ of the fatty acids present in cottonseed.

The influence of fatty acids in meat flavor was studied by Jenschke et al. (2008), who observed that when the percentage of $\mathrm{C}_{18: 2 \mathrm{n}-6}$ increased, the unpleasant flavor decreased, while when the concentration of $\mathrm{C}_{18: 2 \text { cis 9-trans 11 }}$ and $\mathrm{C}_{20: 1 \mathrm{n}-9}$ increased, the unpleasant flavor was more evident. LaBrune et al. (2008) reported that a lipid-rich diet with flaxseed increases the percentage of linoleic acid without changing the flavor.

The quicker oxidation of unsaturated fatty acids, especially those with more than two double bonds, is an important regulator of meat shelf life (Wood et al., 2003). Arachidonic acid, for example, is more susceptible to lipid oxidation during heating and has been associated with unpleasant flavor (Mottram, 1998). However, this association of lipid association with alteration of aroma and flavor does not seem to be confirmed since the content of total unsaturated fatty acids was unaltered.

\section{Conclusions}

There is a decreasing linear relationship between the cottonseed level in the diet and the intramuscular fat of meat from Nellore steers. The increase of cottonseed levels in the feed of Nellore calves does not change the concentration of protein, ashes, conjugated linoleic acidor saturated and total unsaturated fatty acids. The utilization of up to $34.09 \mathrm{~kg}$ of cottonseed per $100 \mathrm{~kg}$ of diet of Nellore steers does not cause lipid oxidation of meat and does not change shear force or meat and fat color. The aroma and flavor of meat are negatively altered by the addition of cottonseed above 27.51 and $34.09 \mathrm{~kg} / 100 \mathrm{~kg}$ of the diet, respectively.

\section{References}

ASSOCIATION OF OFFICIAL ANALYTICAL CHEMISTS - AOAC. Official methods of analysis. 18.ed. Maryland: AOAC, 2007.

BALDWIN, R.L.; ALLISON, M.J. Rumen metabolism. Journal of Animal Science, v.57, n.2, p.462-477, 1983.

BAUMAN, D.E.; GRIINARI, J.M. Regulation and nutritional manipulation of milk fat: low-fat milk syndrome. Livestock Production Science, v.70, n.1-2, p.15-29, 2000.

BOLTE, M.; HESS, B.W.; MEAN, W.J. et al. Feeding lambs higholeate or high-linoleate safflower seeds differentially influences carcass fatty acid composition. Journal of Animal Science, v.80, n.3, p.609-616, 2002.

BONANOME, A.; GRUNDY, S.M. Effect of dietary stearic acid on plasna cholesterol and lipoprotein levels. The New England Journal of Medicine, v.318, n.19, p.1244-1248, 1988.

BRESSAN, M.C.; ODA, S.N.I.; CARDOSO, M.G. et al. Efeitos dos métodos de abate e sexo na composição centesimal, perfil de ácidos graxos e colesterol da carne de capivaras. Ciência e Tecnologia de Alimentação, v.24, n.2, p.236-242, 2004.

CHRISTIE, W.W. A simple procedure for rapid transmethilation of glycerolipids and cholesterol esters. Journal of Lipid Research, v.23, n.7, p.1072, 1982

CRANSTON, J.J.; RIVERA, J.D.; GALYEAN, M.L. et al. Effects of feeding whole cottonseed and cottonseed products on performance and carcass characteristics of finishing beef cattle. Journal of Animal Science, v.84, n.8, p.2186-2199, 2006.

COSTA, D.P.B.; ABREU, J.B.R.; MOURÃO, R.C. et al. Características de carcaça de novilhos inteiros Nelore e $\mathrm{F}_{1}$ Nelore $\mathrm{x}$ Holandês. Ciência Animal Brasileira, v.8, n.4, p.687-696, 2007.

COSTA, D.P.B.; RODRIGUES, V.C.; SILVA J.C.G. et al. Qualidade da carne de novilhos Nelore e $F_{1}$ Nelore x Sindi. Archivos de Zootecnia, v.57, n.219, p.345-348, 2008.

DUNNE, P.G.; MONAHAN, F.J.; O'MARA, F.P. et al. Colour of bovine subcutaneous adipose tissue: A review of contributory factors, associations with carcass and meat quality and its potential utility in authentication of dietary history. Meat Science, v.81, n.11, p.28-45, 2009

FELÍCIO, P.E. Qualidade da carne bovina: características físicas e organolépticas. In: REUNIÃO ANUAL DA SOCIEDADE BRASILEIRA DE ZOOTECNIA, 36., 1999, Porto Alegre. Anais... Porto Alegre: Sociedade Brasileira de Zootecnia, 1999. p.89-97.

FELTON, E.E.D.; KERLEY, M.S. Performance and carcass quality of steers fed different sources of dietary fat. Journal of Animal Science, v.82, n.6, p.1794-1805, 2004.

GIBB, D.J.; OWENS, F.N.; MIR, P.S. et al. Value of sunflower seed in finishing diets of feedlot cattle. Journal of Animal Science, v.82, n.9, p.2679-2692, 2004. 
GILLIS, M.H.; DUCKETT, S.K.; SACKMANN, J.R. Effects of supplemental rumen-protected conjugated linoleic acid or corn oil on fatty acid composition of adipose tissues in beef cattle. Journal of Animal Science, v.82, n.5, p.1419-1427, 2004.

HARA, A.; RADIN, N.S. Lipid extration of tissues of low-toxicity solvent. Analytical Biochemistry, v.90, n.1, p.420-426, 1978.

HRISTOV, A.N.; KENNINGTON, L.R.; MCGUIRE, M.A. et al. Effect of diets containing linoleic acid- or oleic acid-rich oils on ruminal fermentation and nutrient digestibility, and performance and fatty acid composition of adipose and muscle tissues of finishing cattle. Journal of Animal Science, v.83, n.6, p.1312-1321, 2005.

HUERTA-LEIDENZ, N.O.; CROSS, H.R.; LUNT, D.K. et al. Growth, carcass traits, and fatty acid profiles of adipose tissues from steers fed whole cottonseed. Journal of Animal Science, v.69, n.9, p.3665-3672, 1991.

IRIE, M. Optical evaluation of factors affecting appearance of bovine fat. Meat Science, v.57, n.1, p.19-22, 2001.

JENKINS, T.C.; McGUIRE, M.A. Major advances invnutrition: impact on milk composition. Journal of Dairy Science, v.89, n.4, p.1302-1310, 2006.

JENSCHKE, B.E.; BENTON, J.R.; CALKINS, C.R. et al. Chemical and sensory properties of beef of known source and finished on wet distillers grains diets containing varying types and levels of roughage. Journal of Animal Science, v.86, n.4, p.949-959, 2008.

JUNQUEIRA, J.O. Qualidade das carcaças de bovinos jovens, machos e fêmeas, cruzados Marchigiana vs. Nelore, terminados em confinamento. 1996. 55f. Tese (Mestre em Zootecnia) Faculdade de Zootecnia e Engenharia de Alimentos/Universidade de São Paulo, Pirassununga.

KÖPPEN, W. Das geographic system der climate: handbuch der klimatologie. Berlim: Bortraeger, 1938. p.1-44.

LABRUNE, H.J.; REINHARDT, C.D.; DIKEMAN, M.E. et al. Effects of grain processing and dietary lipid source on performance, carcass characteristics, plasma fatty acids, and sensory properties of steaks from finishing cattle. Journal of Animal Science, v.86, n.1, p.167-172, 2008.

MADRUGA, M.S.; VIEIRA, T.R.L.; CUNHA, M.G.G. et al. Efeito de dietas com níveis crescentes de caroço de algodão integral sobre a composição química e o perfil de ácidos graxos da carne de cordeiros Santa Inês. Revista Brasileira de Zootecnia, v.37, n.8, p.1496-1502, 2008.

MEDEIROS, S.R.; TORRES, R.A.A.; BITENCOURT, L.P. et al. Efeito do caroço de algodão na qualidade do "Longissimus dorsi" de bovinos de diferentes grupos genéticos terminados em confinamento. In: REUNIÃO ANUAL DA SOCIEDADE BRASILEIRA DE ZOOTECNIA, 42., 2005, Goiânia. Anais... Goiânia: Sociedade Brasileira de Zootecnia/Gmosis, [2005]. (CD-ROM).

MIR, P.S.; MIR, Z.; MCALLISTER, T.A. et al. Effect of sunflower oil and vitamin $\mathrm{E}$ on beef cattle performance and quality, composition and oxidative stability of beef. Canadian Journal of Animal Science, v.83, n.1, p.53-66, 2003.

MIR, P.S.; MCALLISTER, T.A.; SCOTT, S. et al. Conjugated linoleic acid enriched beef production. The American Journal of Clinical Nutrition, v.79, n.6, p.1207-1211, 2004.

MIR, P.S.; DUGAN, M.E.R.; HE, M.L. et al. Effects of dietary sunflower seeds and tylosin phosphate on production variables, carcass characteristics, fatty acid composition, and liver abscess incidence in crossbred steers. Journal of Animal Science, v.86, n.11, p.3125-3136, 2008.

MOTTRAM, D.S. Flavour formation in meat and meat products: a review. Food Chemistry, v.62, n.4, p.415-424, 1998.

NATIONAL RESEARCH COUNCIL - NRC. Nutrients requirements of beef cattle. 7.ed. Washington: National Academy of Sciences, 1996. 244p.

NATIONAL RESEARCH COUNCIL - NRC. Nutrients requirements of dairy cattle. 7.ed. Washington: National Academy of Sciences, 2001. 381p.
NELSON, M.L.; BUSBOOM, J.R.; ROSS, C.F. et al. Effects of supplemental fat on growth performance and quality of beef from steers fed corn finishing diets. Journal of Animal Science, v.6, n.4, p.936-948, 2008.

OLIVEIRA, R.L.; LADEIRA, M.M.; BARBOSA, M.A.A.F. et al. Ácido linoléico conjugado e perfil de ácidos graxos no músculo e na capa de gordura de novilhos bubalinos alimentados com diferentes fontes de lipídeos. Arquivo Brasileiro de Medicina Veterinária e Zootecnia, v.60, n.1, p.169-178, 2008.

OWENS, F.N.; GILL, D.R.; SECRIST, D.S. et al. Review of some aspects of growth and development of feedlot cattle. Journal of Animal Science, v.73, n.10, p.3152-3172, 1995.

PESCE, D.M.C. Efeito da dieta contendo caroço de algodão no desempenho, características quantitativas da carcaça e qualitativas da carne de novilhos Nelore confinados. 2008. 155f. Tese (Doutor em Zootecnia) - Faculdade de Zootecnia e Engenharia de Alimentos/Universidade de São Paulo, Pirassununga.

PRESTON, R.L.; BARTLE, S.J.; RULE, D.C. Effect of whole cottonseeds in cattle finishing diets on growth, efficiency and body composition. Asian-Australasian Journal of Animal Sciences, v.2, n.2, p.505-506, 1989.

PURCHAS, R.W. An assesment of the role or $\mathrm{pH}$ differences in determining the relative tenderness of meat from bulls and steers. Meat Science, v.27, n.2, p.129-140, 1990.

RICE, E.E. Contenido en nutrientes y valor nutritivo de la carne y productos cárnicos. In: PRICE, J.F.; SCHWEIGHT, B.S. Ciencia de la carne y de los productos carnicos. 2.ed. Madri: ACRIBIA, 1984. p.295-338.

RODRIGUES, V.C.; ANDRADE, I.F. Características físico-químicas da carne de bubalinos e de bovinos castrados e inteiros. Revista Brasileira de Zootecnia, v.33, n.6, p.1839-1849, 2004.

SACKMANN, J.R.; DUCKETT, S.K.; GILLIS, M.H. et al. Effects of forage and sunflower oil levels on ruminal biohydrogenation of fatty acids and conjugated linoleic acid formation in beef steers fed finishing diets. Journal of Animal Science, v.8, n.12, p.3174-3181, 2003.

SAINZ, R.D. Qualidade das carcaças e da carne bovina. In: CONGRESSO BRASILEIRO DAS RAÇAS ZEBUÍNAS, 2., 1996, Uberaba. Anais... Uberaba: Associação Brasileira dos Criadores de Zebu, 1996. (CD-ROM).

SAVELL, J.; MILLER, R.; WHEELER, T. et al. Standardized Warner-Bratzler shear force procedures for genetic evaluation. 1998. Available at: <http://savell-j.tamu.edu/shear.html > Accessed on: Jan 26, 2008.

SCHNEIDER, C.L. et al. Dietary stearic acid reduces cholesterol absorption and increases endogenous cholesterol excretion in hamsters fed cereal-based diets. The Journal of Nutrition, v.130, n.5, p.1232-1238, 2000.

SHACKELFORD, S.D.; KOOHMARIE, M.; CUNDIFF, L.V. et al. Heritabilities and phenotypic and genetic correlations for bovine postrigor calpastatin activity, intramuscular fat content, WarnerBratzler shear force, retail product yield, and growth rate. Journal of Animal Science, v.72, n.4, p.857-863, 1994.

SHAHIDI, F.; WANASUNDARA, P.D. Phenolic antioxidants. Critical Reviews in Food Science and Nutrition, v.32, n.1, p.67-103, 1992.

SHERBECK, J.A.; TATUM, J.D.; FIELD, T.G. et al. Effect of phenotypic expression of Brahman breeding on marbling and tenderness traits. Journal of Animal Science, v.74, n.2, p.304-309, 1996.

SILVA, D.J.; QUEIROZ, A.C. Análise de alimentos: métodos químicos e biológicos. 3.ed. Viçosa, MG: UFV, 2002. 235p.

SILVA, J.C.G.; RODRIGUES, V.C.; NETO, O.C. et al. Perfil de ácidos graxos de bovinos e búfalos terminados em confinamentos, Revista Universidade Rural, Série Ciência da Vida, v.26, n.1, p.79-93, 2006.

SILVA, S.L.; LEME, P.R.; PUTRINO, S.M. et al. Fatty acid composition of intramuscular fat from Nellore steers fed dry or high moisture corn and calcium salts of fatty acids. Livestock Science, v.122, n.2, p.290-295, 2009. 
VALADARES FILHO, S.C.; MAGALHÃES, K.A.; ROCHAJÚNIOR, V.R. et al. Tabelas brasileiras de composição de alimentos para bovinos. 2.ed. Viçosa, MG: UFV, 2006. 329p.

VAN SOEST, P. J.; ROBERTSON, J. B.; LEWIS, B. A.; Methods for dietary fiber, Neutral detergent fiber, and nonstarch polysaccharides in relation to animal nutrition. Journal of Dairy Science, v.74, n.10, p.3583-3597, 1991.
WYNCKE, W. Direct determination of the thiobarbituric acid value in trichloroacetic acid extracts of fish as a measure of oxidative rancidity. Fette-Scifen Anstrichmittel, v.72, n.1, p.1084-1087, 1970.

WOOD, J.D.; ENSER, M.; FISHER, A.V. et al. 58 meat quality and composition. Proceedings of the Nutrition Society, v.58, n.2, p.363-370, 1999.

WOOD, J.D.; RICHARDSON, R.L.; NUTE, G.R. et al. Effects of fatty acids on meat quality: a review. Meat Science, v.66, n.1, p.21-32, 2003. 